\title{
Biological monitoring of genotoxicity to organophosphate pesticide exposure among rice farmers: Exposure-effect continuum study
}

\begin{abstract}
Vivien $\mathrm{H}, \mathrm{BSc}^{1}$, Hashim Z, $\mathrm{PhD}^{2 *}$, Ismail P, $\mathrm{PhD}^{3}$, Md Said S, $\mathrm{MD}^{4}$, Omar D, $\mathrm{PhD}^{5}$, Bahri Mohd Tamrin SH, $\mathrm{PhD}^{6}$

1- Tutor, Dept., of Environmental and Occupational Health, Faculty of Medicine and Health Sciences, University Putra Malaysia, Serdang, Malaysia. 2- Professor, Dept., of Environmental and Occupational Health, Faculty of Medicine and Health Sciences, University Putra Malaysia, Serdang, Malaysia.3-Professor, Dept., of Biomedical Sciences, Faculty of Medicine and Health Sciences, University Putra Malaysia, Serdang, Malaysia. 4- Medical Lecturer, Dept., of Community Health, Faculty of Medicine and Health Sciences, University Putra Malaysia, Serdang, Malaysia. 5- Professor, Dept., of Plant Protection, Faculty of Agriculture, University Putra Malaysia, Serdang, Malaysia. 6-Associate Prof., Dept., of Environmental and Occupational Health, Faculty of Medicine and Health Sciences, University Putra Malaysia, Serdang, Malaysia.
\end{abstract}

\begin{abstract}
Received: October 2013, Accepted: February 2014

Background: This study has used biomarker of exposure-effect continuum to examine the biological characteristics of organophosphate (OP) toxicity and its genotoxic effect among rice farmers.

Materials and Methods: A cross-sectional study was conducted among 160 pesticide exposed rice farmers and 160 adults from the fishing village as the unexposed group. They share the common socio-economical background for inter-individual comparison in human toxicology assessment. In this study depression of blood cholinesterase is used as a biomarker of exposure to OP toxicity. Two genotoxic assays (micronuclei and comet assay) were conducted as a biomarker of genotoxic effect among the adult population. In this context, micronuclei assay is used to indicate the chromosome breakage and comet assay to estimate the possible DNA damage.

Results: The study showed a significant difference of blood cholinesterase level $(p=0.001)$ between the exposed-unexposed groups. Besides, the results showed that farmers had at least 2-2.5 folds of significant increase ( $p=0.001)$ in $\mathrm{MN}$ frequency (in 1000 cells) and comet tail length $(\mu \mathrm{m})$ compared to the unexposed group. In addition, regression analysis among farmers showed that blood cholinesterase level decreased with the genotoxic effects. A small variation $\left(R^{2}=0.148\right)$ of $\mathrm{MN}$ frequency could be explained by the depression of blood cholinesterase level; however, a significant reduction $(p=0.001)$, with strong changes $\left(R^{2}=0.712\right)$ in comet tail length was attributed to the depression of blood cholinesterase levels. Risk factors like age, body mass index, smoking status and years of working showed the different strength of the relationship with these genotoxic effects.

Conclusions: This study suggests that chronic exposure to OP shows an inhibition to blood cholinesterase level, which is associated with the potential DNA breakage as indicated by comet assay. Age, smoking and years of working are the contributing factors influencing the biomarker of effects.
\end{abstract}

Keywords: Organophosphate, Cholinesterase, Depression, Chromosomal Breakage, DNA Damage.

\section{Introduction}

Over the past 60 years, various organophosphates (OP) insecticides have been introduced as the replacement for legally banned organochlorine (OC) used in the markets. In a global rice production area in Southeastern Asia, at least $40 \%$ of the total cost was spent to subsidize OP insecticides used by rice farmers [1]. Unfortunately, by the year 2005, a report from Pesticide Action Network Asia and the Pacific (PANAP) highlighted that at least $39.5 \%$ of

\footnotetext{
Corresponding author: Zailina Hashim, Dept., of Environmental and Occupational Health, Faculty of Medicine and Health Sciences, University Putra Malaysia, Serdang, Malaysia.

Email: zailina@medic.upm.edu.my
} 
the insects resistant to OP, with approximately 542 species showed resistance to the total of 316 different insecticide compounds [2].

In view of this, the frequency and dosage of insecticides used by farmers is expected to increase in order to cope with the insects' rapid evolution process of its genetic adaptation. In this study, the principle of human biological monitoring is used to identify and quantify the level of exposure and health effect to the OP contaminants [3]. In order to characterize the risk of potential health effect, dose monitoring (=exposure biomonitoring) is complemented by studying together with biological effects (=effect biomonitoring). Pathway for biological measurements as suggested in this context is adapted as shown in Figure 1.

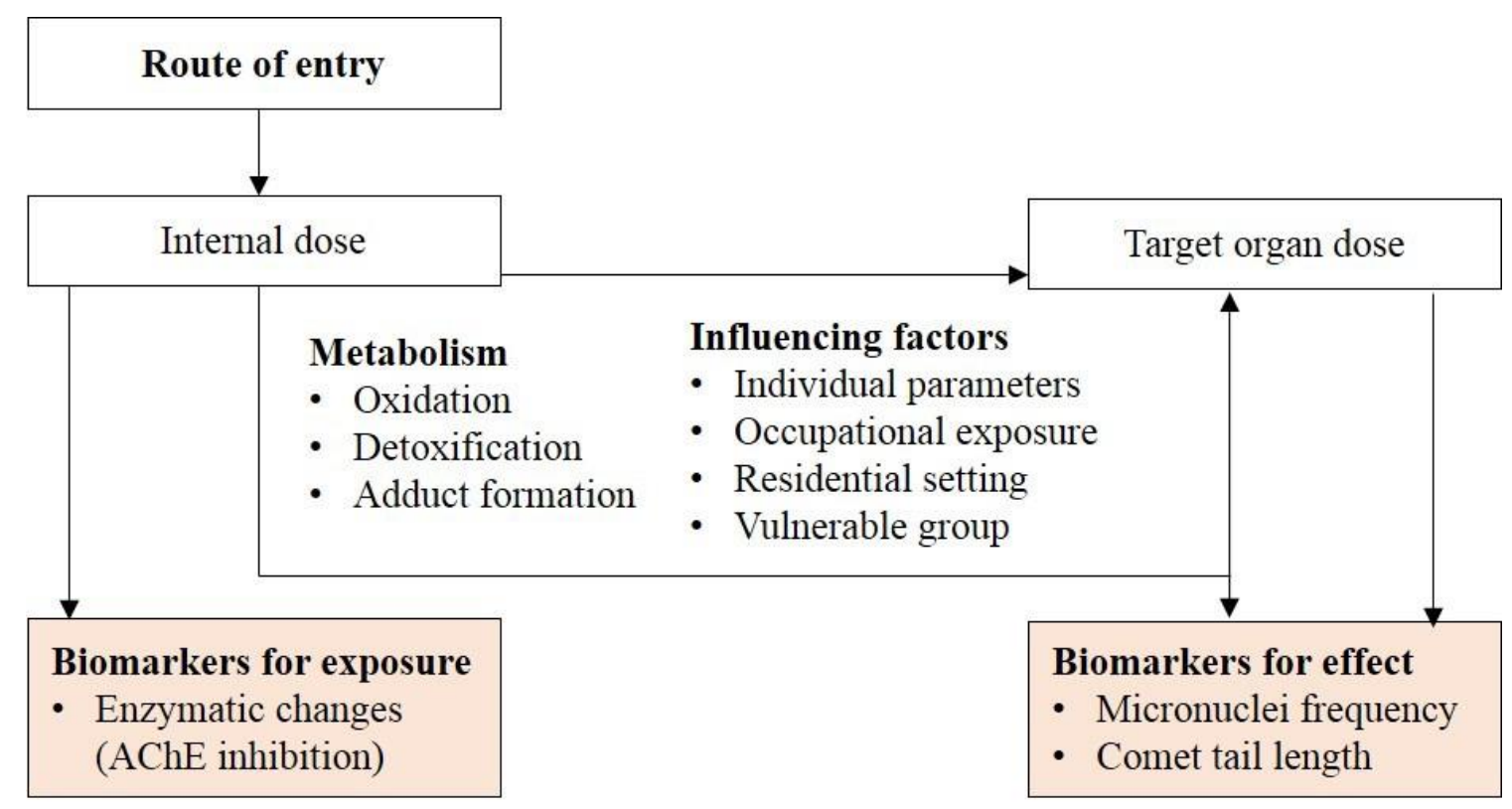

Figure 1: Pathways for biological measurements of mixture of OP (Source: Adapted from [3])

As shown in Figure 1, the primary mechanism of OP toxicity involves the inhibition of the acetyl cholinesterase (AChE) in the central and peripheral nervous system. This has been widely accepted by the occupational practitioner as an effective biomarker of OP exposure [4-6]. In fact, mixture of OP as the esters of phosphoric acid shares a common biochemical mechanism for additive chronic and/or acute health effects [7-8].

Over the years, monitoring of the OP induced chronic effect at the cellular level is of interest. Past studies suggested that the reduction in activity of $\mathrm{AChE}$ demonstrates a significant association with the increase of oxidative stress and lipid per oxidation among farmers who were chronically exposed to OP [9-12]. In fact, the mechanisms of AChE inhibition from OP exposure to increase the potential oxidative stress have been studied by Banerjee [13]. Theoretically, increased formation of reactive oxygen species (ROS) during metabolism may cause oxidative damage to the cellular DNA [14-15]. The background of this principle further suggested that the elevated ROS level and reduction of ROS 
scavenger and antioxidant enzymes are associated to cause damage to nucleic acids, proteins and lipids. This might partly exert their effect to induce chromosomal instability, mutations, loss of organelle functions, cause membrane damage and undergo a multistage of carcinogenesis process (16-18).

Currently, there is a growing concern on OP for its possible chronic effects to exert harmful genotoxic risk among farmers due to their long-term occupational exposure [1922]. However, the potential association between the depressions of $\mathrm{AChE}$ to the potential genotoxic effect of chronic OP exposure has not been well investigated. Therefore, the question arises whether the evidence association between oxidative stress and depression of AChE level will also mark the AChE reduction and induce genotoxic risks [23]. The aim of this study is to fill the knowledge gap by biomonitoring the potential cholinesterase inhibition and genotoxic effects from OP exposure among the study population.

\section{Materials and Methods}

The study was approved by the Ethics Committee of the University Research Involving Human Putra Malaysia (UPM/FPSK/100-9/2-JKEUPM). A total of 160 rice farmers $(40.13 \pm 10.56)$ who reported to have at least 2 years of farming experience were exposed to a mixture of OPs activity were recruited to participate in this study. They were considered as the rural farming community living in proximity to the paddy farmland. Therefore, they were presumed to have cumulative exposure to low level of pesticide through pesticide drift, deposition, sedimentation, leaching and drainage. An unexposed group consisting of 160 villagers $(40.22 \pm 9.75)$ from fishing village was selected as an inter-individual comparison of toxicological effect.

\section{Biomarker of exposure}

The primary mechanism of toxicity of OP pesticide is by phosphorylation of the acetyl cholinesterase enzyme (AChE) at the nerve endings [5-6, 24-25]. In this study, monitoring of blood cholinesterase level is a useful tool which was used as a biomarker of exposure to OP pesticide.

Invasive manner of collecting biological samples has been the obstacles in human health study, particularly among rural villagers. Therefore, blood cholinesterase test kit (Lovibond, AF267; Tintometer Ltd., UK) is used to determine the exposure level with only $10 \mu 1$ of capillary blood from the finger tips. This test kit which works based on the colorimetric principle is helpful to ease the laboratory analysis with an on-site blood cholinesterase level estimation.

Finger pricked blood is pipetted to round test tube which contained of $0.5 \mathrm{ml}$ of indicator solution (Bromothymol blue solution) followed by $0.5 \mathrm{ml}$ of substrate solution (Acetylcholine Percholarate). The test tube was then mixed thoroughly and transferred to $2.5 \mathrm{~mm}$ cuvettes. Next, the $2.5 \mathrm{~mm}$ of cuvettes was placed in the colour compartment to view the indicator colour through a prism. The result is read based on the acid-base blood cholinesterase level (\%) obtained through the $\mathrm{pH}$ colour indicator. This colorimetric principle is based on the normal breakdown of acetylcholine as shown in Equation 1. The presence of acetic acid determines the normal workout between acetylcholine and acetyl cholinesterase; otherwise, it forms the bases due to the accumulation of acetylcholine.

Acetylcholine $\rightarrow$ Acetic acid + choline (Equation 1) 


\section{Biomarker of effect (Genotoxicity assessment)}

Biomarkers of effect are biological indicators of the body's response to exposure. The effect of OP exposure is determined by monitoring the genotoxicity consequences of sub-clinical changes. The genotoxic effect is measured through the micronuclei and comet assay. To ensure biological samples are collected in a convenient and less invasive manner, exfoliated buccal mucosa cells were collected as a sensitive biomarker of genotoxic damage in the target tissues [26 27].

\section{Genotoxicity test (Micronuclei Assay)}

Micronuclei (MN) assay is used as an internal dosimeter to monitor the presence of $\mathrm{MN}$ for chromosome [28]. This is to estimate the possibility of early cancer risk experienced by the study population. This assay was conducted based on the standard protocol from Thomas and Fenech [29].

Buccal mucosa cell specimens collected were first centrifuged at $1500 \mathrm{rpm}$ to wash the cells in the buffer solution $(80 \%$ methanol, absolute ethanol). The supernatant is aspirated off and the buccal cells were smeared on the slide by using a pulling technique and keep air-drying. The cell was fixed with methanol: acetic acid (3:1) solution in a $0.1 \%$ phosphate buffer $(\mathrm{pH} 7.5)$ for 20 minutes. The slide was then stained by Feulgen reaction, followed by counterstaining of the slide with $0.1 \%$ of fast green for 30 seconds and rinsed well with deionized water $\left(\mathrm{dH}_{2} \mathrm{O}\right)$. The slide was then placed face-down to blot away any residual moisture and allowed drying for about 10-15 minutes before analyzing under light microscope with 100x magnification.

The end point is to measure the cells in the presence of $\mathrm{MN}$ (s), which is scored based on the cells presented with a main nucleus and smaller nuclei called MN. The MN was usually round or oval in shape, and their diameter ranged between $1 / 3$ to $1 / 10$, the diameter of the main nucleus.

\section{Genotoxicity test (Comet Assay)}

The Comet Assay, also known as Single-Cell Gel Electrophoresis (SCGE) technique, is a fast and effective way to measure DNA damage by estimating the comet tail length $(\mu \mathrm{m})$. This assay was based on the standard procedure from Comet Assay Kit (Trevigen, USA).

Collected buccal mucosa cell specimens were first centrifuged for 1 minute at 2500 rpm. Next, Low Melting-point Agarose (LMA) melted in a beaker of boiling water, with the cap loose in 5 minutes and then kept cool at $37^{\circ} \mathrm{C}$ water bath for at least 20 minutes. This was followed by pipetted $75 \mu \mathrm{L}$ of 1:10 (v/v) aliquot onto comet slide. Lysis process initiated by placing the slide at $4^{\circ} \mathrm{C}$ in the dark for 10 minutes, then immersed in pre-chilled lysis solution for 60 minutes. Cells were further denatured by immersion in freshly prepared alkaline solution, $\mathrm{pH}>13$ for 45 minutes at room temperature in the dark. The cells were now ready for electrophoresis system and set the power supply was set at 1 volt $/ \mathrm{cm}$. After 1 hour, the slide was rinsed by dipping in deionized water $(\mathrm{dH} 2 \mathrm{O})$, and immersing slide in $70 \%$ ethanol for 5 minutes. The slides then were stained with 50 $\mu \mathrm{L}$ of dilute SYBR green before viewing under fluorescent microscope (DM2500, LEICA) with magnification 100x and the images were captured. The cells were then analyzed by using the commercially available TriTek Comet Score (version 1.5) software (TriTek Corp., Sumerduck, VA, USA). The tail length was measured $(\mu \mathrm{m})$ to indicate the distance of DNA migration from the body of nuclear core and it was used to evaluate the extent of DNA damage. 


\section{Results}

Table 1 summarizes the socio-demographic characteristic of the study population. The
320 participates were all male and Muslims, who did not drink alcohol. Both exposed and unexposed groups had similar socioeconomical background.

Table 1: Demographic characteristics of study population $(N=320)$

\begin{tabular}{lcccc}
\hline & \multicolumn{2}{c}{ Rice farmer $(N=160)$} & \multicolumn{2}{c}{ Unexposed $(N=160)$} \\
\cline { 2 - 5 } Demographic characteristics & $N(\%)$ & Mean (SD) & $N(\%)$ & Mean (SD) \\
\hline Male gender & $160(100)$ & - & $160(100)$ & - \\
Age (year) & - & $40.13(10.56)$ & - & $40.22(9.75)$ \\
Body Mass Index (BMI) & - & $24.05(3.37)$ & - & $23.06(2.59)$ \\
Smoker & $109(68.1)$ & - & $92(57.5)$ & - \\
Farming experience (year) & - & $17.63(11.35)$ & - & - \\
\hline
\end{tabular}

The level of blood cholinesterase is to reflect the biomarker of OP exposure during the farm activity. Table 2 shows there is a significant difference $(p=0.001)$ of blood cholinesterase level between exposed and unexposed groups. When an acid-base $(\%)$ of blood cholinesterase level is estimated, with the average farmers indicated an "overexposed" (41.02\%) level and unexposed group show an average of "normal" (75\%) level.

Table 2: Comparison biomarkers of exposure (blood cholinesterase level) among study population ( $\mathrm{N}=320)$

\begin{tabular}{|c|c|c|c|c|}
\hline \multirow[t]{2}{*}{ Biomarker of exposure } & $\begin{array}{l}\text { Rice farmer } \\
\qquad(N=160)\end{array}$ & $\begin{array}{l}\text { Unexposed } \\
\qquad(N=160)\end{array}$ & \multirow[t]{2}{*}{$t$-statistic ${ }^{a}$} & \multirow[t]{2}{*}{$p$-value } \\
\hline & Mean (SD) & Mean (SD) & & \\
\hline $\begin{array}{l}\text { Blood Cholinesterase } \\
\text { level }^{\text {b }}\end{array}$ & $41.02(24.57)$ & $74.84(15.42)$ & -14.751 & $<0.001 * *$ \\
\hline $\begin{array}{l}* * p \text {-value is significant at le } \\
\text { a Independent } t \text {-test } \\
\text { b Analysis of result based on } \\
\text { 100.0-75.0 (\%): Normal; } \\
62.5-50.0(\%) \text { : Over-exposur } \\
37.5-25.0(\%) \text { : Serious over } \\
0.0(\%) \text { : Very serious and da }\end{array}$ & $\begin{array}{l}\text { holinesterase test } \\
\text { e; } \\
\text { over exposure }\end{array}$ & Lovibond AF267, & tometer Ltd., & K), \\
\hline
\end{tabular}

The study utilized two genotoxic assays, e.g. MN assay and comet assay to evaluate the genotoxic effect. Table 3 suggested that farmers had at least an increase of 2-2.5 folds in genotoxic effects as compared to the unexposed group. The significant difference 
of MN frequency (per 1000 cells) and comet tail length $(\mu \mathrm{m})$ are crucial to highlight that farmers are at high risk of the genotoxic effects due to the nature of their work as a pesticide applicator as compared to the unexposed group.

Table 3: Comparison of biomarker of effect (genotoxic risk) among study population $(\mathrm{N}=320)$

\begin{tabular}{lcccc}
\hline Biomarker of effect & $\begin{array}{c}\text { Paddy farmer } \\
(N=160)\end{array}$ & $\begin{array}{c}\text { Unexposed } \\
(N=160)\end{array}$ & $\begin{array}{c}t \text { - } \\
\text { statistic }{ }^{\text {a }}\end{array}$ & $p$-value \\
\cline { 2 - 4 } & Mean (SD) & Mean (SD) & & \\
\hline $\begin{array}{l}\text { Micronuclei (per 1000 } \\
\text { cells) }\end{array}$ & $14.48(4.20)$ & $5.46(1.67)$ & 25.2 & $<0.001 * *$ \\
Comet tail length $(\mu \mathrm{m})$ & $24.35(8.20)$ & $12.85(3.10)$ & 16.6 & $<0.001 * *$ \\
\hline$* *$-value is significant at level 0.001 & & & \\
a Independent $t$-test
\end{tabular}

The difference between the genotoxic effects examined by MN assay and comet assay is due to the variations in the type of DNA alterations in the test system. The MN assay is commonly used to detect fixed mutations which persist for at least one mitotic cycle; whereas, comet assay is a biomarker for the repairable DNA lesions or single and double stranded DNA that breaks at a single cell. In other words, MN assay is widely used to indicate early genotoxic risk due to chromosomal breakage; in contrast, comet assay is used to estimate the potential of DNA strand breaks in a cell.

Table 4: Relationship between blood cholinesterase level and genotoxic effects among rice farmers $(\mathrm{N}=160)$

\begin{tabular}{lcccc}
\hline \multirow{2}{*}{ Variables $^{\text {a }}$} & \multicolumn{2}{c}{ Micronuclei (per 1000 cells) } & \multicolumn{2}{c}{ Comet tail length $(\mu \mathrm{m})$} \\
\cline { 2 - 5 } Block 1 & $\beta$-coefficient & $\begin{array}{c}r \text {, correlation } \\
\text { coefficient }\end{array}$ & $\beta$-coefficient & $\begin{array}{c}r \text {, correlation } \\
\text { coefficient }\end{array}$ \\
\hline Age & 0.063 & 0.264 & $0.766^{* *}$ & 0.830 \\
BMI & 0.180 & 0.209 & 0.049 & 0.165 \\
Smoker ${ }^{\text {b }}$ & $-1.323^{*}$ & -0.155 & $-1.745^{*}$ & -0.102 \\
Year of & $0.162^{* *}$ & 0.335 & -0.126 & 0.697 \\
employment & 0.136 & & 0.699 & \\
Adjusted $R^{2}$ & $7.248^{* *}$ & & $93.113^{* *}$ & \\
$F$-statistics & & & $-0.042^{*}$ & \\
\hline Block 2 & & & & \\
\hline Blood & & & 0.712 & \\
cholinesterase & -0.023 & -0.146 & $79.662^{* *}$ & \\
level & & & & \\
Adjusted $R^{2}$ & 0.148 & & & \\
$F$-statistics & $6.519^{* *}$ & & & \\
\hline
\end{tabular}

${ }^{\text {a }}$ Simple linear Regression (SLR) by block

${ }^{\mathrm{b}}$ For coding for categorical variables $(1=$ smoker, $0=$ non-smoker)

'Included predictor: Blood cholinesterase level and covariate (Block 1)

** $P$-value is significant at level 0.01

* P-value is significant at level 0.05 
Table 4 shows the relationship between blood cholinesterase and the genotoxic effects. Risk factors, such as, age, body mass index (BMI), smoking and year of employment (as farmer) are introduced as covariate which may influence the genotoxic risks in the study population. Both genotoxic effects indicated an inverse relationship with the level of blood cholinesterase. The result indicated that the blood cholinesterase significantly decreased with MN frequency ( $p=0.001)$ and comet tail length $(p=0.001)$. Regression models for adult farmers suggested that $14.8 \%$ of MN frequency (per 1000 cells) were explained by the blood cholinesterase level; however, $71.2 \%$ of comet tail length $(\mu \mathrm{m})$ changes were attributed by the depression of blood cholinesterase levels among adult farmers.

Overall, there is a significant increase in adjusted $R^{2}$ from block 1 (MN assay and covariate: $R^{2}=0.136$; Comet assay and in a way that covariate: $\left.R^{2}=0.699\right)$ to block 2 that the combination of the predictor and the covariates seems to contribute to the variance in the outcome genotoxic effect.

\section{Discussion}

The present study used biomarker of exposure-effect continuum to examine the biological characteristics of OP toxicity and its genotoxic risk among rice farmers. The result is in agreement with other studies which showed a significant reduction in blood cholinesterase level among farmers [225, 30]. Besides, genotoxic effects shown in the current study are consistent with previous studies. Both the effect of chromosomal breakage (MNformation) and DNA strand breaks (comet tail length) showed a significant increase in farmers as compared with the unexposed group [20, 31-33].
As shown in Figure 1, there are factors which influence the biomarker effects' output, such as the role of lifestyle, individual parameters and occupational factors. In this study, we examine the changes in blood cholinesterase level with the genotoxic effects by evaluating the selected risk factors, such as, age, BMI, smoking and year of employment (as a farmer).

Among these, occupational exposure such as the year of working experience is of particular importance due to farmers' work nature as a pesticide applicator. This is considered as a crucial factor contributing to the genotoxic effects [34-35]. Besides, it is known that individual factors such as age, BMI, and smoking are also the predisposing factors contributing the cancer development [28]. This finding showed that age, smoking and obesity contributed to the bodyfunction impairments over time. In other words, dynamic interaction between individual predispositions and genotype were associated with the production of reactive oxygen species (ROS) under a sustained stress exogenous and endogenous environment, which characterize the increase in intracellular oxidative stress modulating the multistage carcinogenic process over an extended period of time $[14,18,36]$.

The different response presented by MN assay and comet assay to cholinesterase inhibition in this study is in agreement with previous studies [22, 38]. These studies suggested that the spontaneous hydrolysis of OP from the active site (serine) of acetyl cholinesterase enzyme is very slow, and may cause irreversible impairment due to cumulative and long-term toxic effects among farmers. Under this continuous environmental stress, ROS are more inclined to accumulate and produce over a long period of time after chronic and low level of OP exposure [11, 22, 38-39]. 
Furthermore, the association between blood cholinesterase activities with ROS suggest a relevant gene-pesticide interaction which could further lead to genotoxic risk and carcinogenicity. Since the increases in stress of ROS and reducing of ROS scavengers and antioxidant enzymes may lead to a significant damage to cell structures [15, 18], a significant damage may occur to the cell structure and induce somatic mutation and neoplastic transformation over time. Indeed, cancer initiation and progression have been associated with oxidative stress through increased DNA mutations or induced DNA damage and genomic instability $[36,40]$.

\section{Conclusion}

This study suggests that the chronic exposure to OP marks an inhibition to blood cholinesterase level, which is associated with the potential DNA breakage as indicated by comet assay. However, the biomarker for short-term acute exposure showed no chromosomal breakage from MN frequency. Nevertheless, further study is needed to further quantify the potential body burden perceived from OP exposure and estimate the adverse effect from chronic exposure at the cellular level of the organism by considering the weight of evidence.

\section{Acknowledgements}

This work was supported by the Research University Grant Scheme (RUGS) Initiative6 [grant number: 9337400] under Research Management Centre (RMC), University Putra Malaysia from 2012-2014.

Conflict of Interest: Non declared.

\section{References}

1. Magallona ED. (1989). Effects of insecticides in rice ecosystems in Southeast Asia. In: Bourdeau P, Haines JA, Klein W, Krishna Murti CR, Ecotoxicology and Climate. New York: John Wiley \& Sons Ltd. P265-97.

2. Watts M (2010). Pesticides: Sowing poison, growing hunger, reaping sorrow. In Rengam SV, editors. $2^{\text {nd }}$ ed. Malaysia: Pesticide Action Network (PAN) Asia and the Pacific. P 1-104.

3. Kapka-Skrzypczak L, Cyranka M, Skrzypczak M, Kruszewski M. Biomonitoring and biomarkers of organophosphate pesticides exposure - state of the art. Ann Agric Environ Med 2011; 18(2): 294-303.

4. Bhalli JA, Khan QM, Nasim A. DNA damage in Pakistani pesticide-manufacturing workers assayed using the Comet assay. Environ Mol Mutagen 2006; 47(8):587-93.

5. Mohebbi GH, Jahangiri A, Hajeb P. Inhibition of acetyl cholinesterase activity farmers exposed to organophosphate pesticides in Bushehr, Iran. AmericanEurasian Journal of Toxicological Sciences 2011; 3(3):127-29.

6. Wilson BW, Arrieta DE, Henderson JD. Monitoring cholinesterases to detect pesticide exposure. Chem Biol Interact 2005; 157158:253-6.

7. Abdullah AR, Bajet CM, Matin MA, Nhan DD, Sulaiman AH. Ecotoxicology of pesticides in the tropical paddy field ecosystem. Environ Toxicol Chem 1997; 16(1):59-70.

8. Dubois KP. The toxicity of organophosphorus compounds to mammals. Bull World Health Organ 1971; 44(1-3):23340.

9. Haque QS, Jamal F, Rastogi SK. Effect of organophosphorus on biochemical parameters on agricultural workers of mango orchards. Asian Journal Biochemistry 2012; 7(1):37-45.

10. Khan DA, Bhatti MM, Khan FA, Naqvi ST. Evaluation of pesticides induced toxicity by oxidative stress and inflammatory biomarkers. Pakistan Armed Forces Medical Journal 2008; (4). Available from: http://www.pafmj.org/showdetails.php?id=20 $8 \& \mathrm{t}=\mathrm{o}$

11. Ogut S, Gultekin F, Kisioglu AN, Kucukoner E. Oxidative stress in the blood of 
farm workers following intensive pesticide exposure. Toxicol Ind Health 2011; 27(9):820-5

12. Santi A, Menezes C, Duarte MM, Leitemperger J, Lopes T, Loro VL. Oxidative stress biomarkers and acetylcholinesterase activity in human erythrocytes exposed to clomazone (in vitro). Interdiscip Toxicol 2011; 4(3):149-53.

13. Banerjee BD, Seth V, Bhattacharya A, Pasha ST, Chakraborty AK. Biochemical effects of some pesticides on lipid peroxidation and free-radical scavengers. Toxicol Lett 1999; 107(1-3):33-47.

14. Bozina N, Bradamante V, Lovric M. Genetic polymorphism of metabolic enzymes $\mathrm{P} 450$ (CYP) as a susceptibility factor for drug response, toxicity, and cancer risk. Arh Hig Rada Toksikol 2009; 60(2):217-42.

15. Waris G, Ahsan H. Reactive oxygen species: role in the development of cancer and various chronic conditions. J Carcinog 2006; 5:14.

16. Alavanja MC, Ross MK, Bonner MR. Increased cancer burden among pesticide applicators and others due to pesticide exposure. CA Cancer J Clin 2013; 63(2):12042.

17. Halliwell B. Oxidative stress and cancer: Have we moved forward? Biochem J 2007; 401(1):1-11.

18. Reuter S, Gupta SC, Chaturvedi MM, Aggarwal BB. Oxidative stress, inflammation, and cancer: how are they linked? Free Radic Biol Med 2010; 49(11):1603-16.

19. Vivien H, Zailina H, Patimah I, Dzolkhifli O, Salmiah MS, Shamsul BMT. Characterization of risk factors for DNA damage among paddy farmworker exposed to mixture of organophosphate. Arch Environ Occup Health 2013; (doi: 10.1080/19338244.2013.823905).

20. Yadav AS, Sehrawat G. Evaluation of genetic damage in farmers exposed to pesticide mixtures. Int $\mathbf{J}$ Hum Genet 2011; 11(2):105-9.

21. Acquavella J, Doe J, Tomenson J, Chester G. Cowell J, Bloemen L. Epidemiologic studies of occupational pesticide exposure and cancer: regulatory risk assessments and biologic plausibility. Ann Epidemiol 2003; 13(1):1-7.

22. How V, Hashim Z, Ismail P, Md Said S, Omar D, Bahri Mohd Tamrin S. Exploring cancer development in adulthood: cholinesterase depression and genotoxic effect from chronic exposure to organophosphate pesticides among rural farm children. J Agromedicine 2014; 19(1): 35-43

23. Elersek T, Filipic M. (2011). Organophosphorous Pesticides-Mechanisms of Their Toxicity. In: Margarita Stoytcheva, Pesticides-The Impacts of Pesticides Exposure. [Internet]. Croatia: In Tech: 2011. Chapter 12. P243-60. Available from: http://www.intechopen.com/books/pesticides -the-impacts-of-pesticidesexposure/ organophosphorous-pesticides-mechanismsof-their-toxicity

24. Cocker J, Mason HJ, Garfitt SJ, Jones K. Biological monitoring of exposure to organophosphate pesticides. Toxicol Lett 2002; 134(1-3):97-103.

25. Bhalli JA, Khan QM, Haq MA, Khalid AM, Nasim A. Cytogenetic analysis of Pakistani individuals occupationally exposed to pesticides in a pesticide production industry. Mutagenesis 2006; 21(2):143-8.

26. Benedetti D, Nunes E, Sarmento M, Porto C, Dos Santos CE, Dias JF, et al. Genetic damage in soybean workers exposed to pesticides: evaluation with the comet and buccal micronucleus cytome assays. Mutat Res 2013; 752(1-2):28-33.

27. Szeto YT, Benzie IF, Collins AR, Choi SW, Cheng CY, Yow CM, et al. A buccal cell model comet assay: development and evaluation for human biomonitoring and nutritional studies. Mutat Res 2005; 578(12):371-81.

28. Battershill JM, Burnett K, Bull S. Factors affecting the incidence of genotoxicity biomarkers in peripheral blood lymphocytes: impact on design of biomonitoring studies. Mutagenesis 2008; 23(6):423-37.

29. Thomas P, Fenech M. (2011). Chapter 17 In DNA Damage Detection In Situ, Ex Vivo, and In Vivo: Methods and Protocols. In: Didenko V, editor. New York: Humana Press; p235-248. (Methods in Molecular Biology Vol.682).

30. Husin LS, Uttaman A, Hisham HJ, Hussain IH, Jamil MR. The effect of pesticide on the activity of serum cholinesterase and current perception threshold on the paddy farmers in the Muda agriultural development area, MADA, Kedah, Malaysia. Med J Malaysia 1999; 54(3):320-4. 
31. Bhalli JA, Ali T, Asi MR, Khalid ZM, Ceppi M, Khan QM. DNA damage in Pakistani agricultural workers exposed to mixture of pesticides. Environ Mol Mutagen 2009; 50(1):37-45.

32. Costa C, Silva S, Coelho P, Roma-Torres J, Teixeira JP, Mayan O. Micronucleus analysis in a Portuguese population exposed to pesticides: preliminary survey. Int $\mathrm{J}$ Hyg Environ Health 2007; 210(3-4):415-8.

33. Undeger U, Basaran N. Assessment of DNA damage in workers occupationally exposed to pesticide mixtures by the alkaline comet assay. Arch Toxicol 2002; 76(7):430-6.

34. Garaj-Vrhovac V, Zeljezic D. Assessment of genome damage in a population of Croatian workers employed in pesticide production by chromosomal aberration analysis, micronucleus assay and Comet assay. J Appl Toxicol 2002; 22(4):249-55.

35. Hashmi I, Khan AD. (2012). Adverse Health Effects of Pesticides Exposure in Agricultural and Industrial Workers of Developing Country. In: Margarita Stoytcheva. Pesticides-The Impacts of Pesticides Exposure. Croatia: In Tech. P155-78.
36. Devasagayam TP, Tilak JC, Boloor KK, Sane KS, Ghaskadbi SS, Lele RD. Free radicals and antioxidants in human health: current status and future prospects. J Assoc Physicians India 2004; 52:794-804.

37. Lukaszewicz-Hussain A. Role of oxidative stress in organophosphate insecticide toxicity- short review. Pestic Biochem Physiol 2010; 98(2):145-50.

38. Bayrami M, Hashemi T, Malekirad AA, Ashayeri H, Faraji F, Abdollahi M. Electroencephalogram, cognitive state, psychological disorders, clinical symptom, and oxidative stress in horticulture farmers exposed to organophosphate pesticides. Toxicol Ind Health 2012; 28(1):90-6.

39. Hernandez AF, Lacasana M, Gil F, Rodríguez-Barranco M, Pla A, LópezGuarnido O. Evaluation of pesticide-induced oxidative stress from a gene-environment interaction perspective. Toxicology 2013; 307:95-102.

40. Visconti R, Grieco D. New insights on oxidative stress in cancer. Curr Opin Drug Discov Devel 2009; 12(2):240-5. 